\title{
Persistence of differences between sheep in methane emission under generous grazing conditions
}

\author{
C. S. PINARES-PATIÑO ${ }^{1,3}$, M. J. ULYATT ${ }^{1 *}$, K. R. LASSEY ${ }^{2}$, T. N. BARRY R \\ AND C. W. HOLMES ${ }^{3}$ \\ ${ }^{1}$ AgResearch Limited, Grasslands Research Centre, Tennent Drive, Private Bag 11008, Palmerston North, \\ New Zealand \\ ${ }^{2}$ National Institute of Water and Atmospheric Research Ltd., P.O. Box 14-901, Kilbirnie, Wellington, \\ New Zealand \\ ${ }^{3}$ Institute of Veterinary, Animal and Biomedical Sciences, Massey University, Palmerston North, \\ New Zealand \\ (Revised MS received 23 January 2003)
}

\begin{abstract}
SUMMARY
Four low and four high methane $\left(\mathrm{CH}_{4}\right)$ emitters were selected from a flock of 20 Romney sheep on the basis of $\mathrm{CH}_{4}$ production rates per unit of intake, measured at grazing using the sulphur hexafluoride $\left(\mathrm{SF}_{6}\right)$ tracer technique. Methane emissions from these sheep were monitored at grazing for four periods (P): October, November, January and February 1999/2000. All measurements were carried out on perennial ryegrass/white clover pasture under generous herbage allowance, and the sheep were maintained on similar pastures during non-measurement periods. The tracer technique was used for all the $\mathrm{CH}_{4}$ measurements and feed DM intake was calculated from total faecal collection and estimated DM digestibility. Data for liveweight (LW), gross energy intake (GEI) and $\mathrm{CH}_{4}$ emission were analysed using split-plot analysis of variance. In addition, a between-period rank order correlation analysis was carried out for $\mathrm{CH}_{4}$ emission data.

Low $\mathrm{CH}_{4}$ emitters were heavier $(P<0 \cdot 05)$ than the high emitters in all the periods, but they did not differ $(P<0 \cdot 05)$ in their gross energy intakes $\left(\mathrm{GEI}: \mathrm{MJ} / \mathrm{kg} \mathrm{LW}{ }^{0.75}\right)$. Low and high $\mathrm{CH}_{4}$ emitters consistently maintained their initial rankings in $\mathrm{CH}_{4}$ yield (\% GEI) throughout the subsequent periods and the correlation analysis of rank order for $\mathrm{CH}_{4}$ yield showed strong between-period correlation coefficients, although this was weaker in the last period. It is suggested that feeding conditions that maximize feed intake (e.g. generous allowance of good quality pasture under grazing) favour the expression and persistence of between-sheep differences in $\mathrm{CH}_{4}$ yield.
\end{abstract}

\section{INTRODUCTION}

Rumen methanogenesis results in the loss of up to $12 \%$ of gross energy intake (GEI) (Johnson et al. 1993). Methane $\left(\mathrm{CH}_{4}\right)$, a potent greenhouse gas, is estimated to contribute about $24 \%$ of anthropogenic global warming, second only to carbon dioxide $\left(\mathrm{CO}_{2}\right)$ (Houghton 1997), and its atmospheric concentration has increased over recent years at the rate of about $0.9 \%$ per year (Crutzen 1995). New Zealand's pastoral farming contributes about $88 \%$ of the national $\mathrm{CH}_{4}$ emission (UNFCCC 1999), which on a per capita basis is 10 times greater than the global average

* To whom all correspondence should be addressed. Email:mwu@paradise.net.nz
(Ministry for the Environment 1997), a consequence of large ruminant livestock and small human populations.

Compared with the other sources of $\mathrm{CH}_{4}$ emission, ruminant $\mathrm{CH}_{4}$ can be manipulated relatively simply (Leng 1993). With appropriate policies, current and potential future technologies and management practices could reduce $\mathrm{CH}_{4}$ emissions per unit of animal product by 25-75\% (Gibbs et al. 1989; Leng 1993; Mosier et al. 1998). However, with the exception of improved feeding management, the current technologies to control $\mathrm{CH}_{4}$ emission from ruminants are seen with pessimism (Johnson et al. 1996; van Nevel \& Demeyer 1996). In addition, for ruminant production systems based on forages, the necessary improvement in feeding management might not only 
be unaffordable, but it may undermine the traditional role of ruminants, which is to utilize low-cost fibrous feed resources. Therefore, the development of costeffective strategies to mitigate ruminant $\mathrm{CH}_{4}$, without causing a negative impact on ruminant production, continues to be a major challenge for ruminant nutritionists and microbiologists (McAllister et al. 1996).

Between-sheep variation in $\mathrm{CH}_{4}$ emission has long been recognized from measurements in respiration chambers (Blaxter \& Clapperton 1965) and in vitro (Demeyer \& van Nevel 1975), and recently confirmed under grazing conditions (Lassey et al. 1997; Ulyatt et al. 1999). The latter authors reported that about $85 \%$ of the variation in daily $\mathrm{CH}_{4}$ production $(\mathrm{g} /$ day) from sheep grazing temperate pastures was due to variation between animals. If such between-animal variability is persistent in the long term, and the animal trait(s) that account for such variation is (are) inherited, breeding of animals for low $\mathrm{CH}_{4}$ emission might be viable (Gibbs et al. 1989).

The present study was planned to test the hypothesis that sheep grazed on pasture will maintain existing differences between animals in methane emitted per unit of feed intake in the medium term.

\section{MATERIALS AND METHODS}

\section{Experimental design and animals}

In early October 1999, 20 Romney wethers, approximately 14 months old, grazing on perennial ryegrass (Lolium perenne)/white clover (Trifolium repens) pasture at AgResearch Grasslands, Palmerston North, New Zealand, were selected on the basis of uniform liveweight $(\sim 45 \mathrm{~kg})$ from a flock of 200 . Methane production rates $(\mathrm{g} / \mathrm{kg}$ dry matter intake, DMI) from each of these sheep were measured by the sulphur hexafluoride $\left(\mathrm{SF}_{6}\right)$ tracer technique (Johnson et al. 1994) for 3 consecutive days. Based on these measurements, eight sheep with contrasting $\mathrm{CH}_{4}$ production rates (four low and four high, $P=0 \cdot 001$ ) were selected and defined as the first measurement period $\left(\mathrm{P}_{1}\right)$. Three subsequent $\mathrm{CH}_{4}$ measurement periods, using the tracer technique, were carried out on the selected sheep in late November $1999\left(\mathrm{P}_{2}\right)$, early January 2000 $\left(\mathrm{P}_{3}\right)$ and late February $2000\left(\mathrm{P}_{4}\right)$. Because one sheep ranked as a low emitter developed chronic lameness at the end of $\mathrm{P}_{1}$ and had to be excluded, the final sheep numbers were three low and four high emitters.

In each period sheep were acclimatized for 5 days to the experimental and management conditions before a 5-day measurement phase began. $\mathrm{CH}_{4}$ production and herbage intake were measured over days 1-4 and samples of rumen contents for volatile fatty acid (VFA) analysis were taken on day 5. Acclimatization was set at only 5 days because the pasture was not changed during or between measurement periods.
Sheep liveweights (LW) were measured at the beginning and end of each period. Weather conditions (maximum and minimum air temperatures and relative humidity) were recorded daily.

\section{Pasture and grazing management}

Two 0.25-ha paddocks of perennial ryegrass/white clover pasture were used in this study. Both paddocks were rotationally grazed. One of the paddocks was exclusively used during each of the 10-day measurement periods, whereas sheep grazed the other paddock between measurement periods. Herbage in both paddocks was maintained in a vegetative stage by grazing with sheep and when required by irrigation.

During the measurement periods a fresh area of pasture was offered each day and controlled by electric fences to give about $12 \%$ of sheep LW as total herbage dry matter (DM) offered, in order to maximize intake (Hodgson 1990).

Fresh drinking water was available ad libitum during all the experimental periods.

\section{Sample collection and laboratory analyses}

Daily $\mathrm{CH}_{4}$ production (g/day) was measured over days $1-4$ by the $\mathrm{SF}_{6}$ tracer technique, following the procedures described by Lassey et al. (1997). Three successful $\mathrm{CH}_{4}$ sampling days were required from each animal.

The DMI $(\mathrm{kg} /$ day) of individual sheep was estimated from the pasture's DM digestibility (DMD), determined by the near-infrared reflectance spectrometry technique (NIRS), in conjunction with the twice-daily collection of total faeces output using a harness and canvas collection bag. Faeces were collected for 3 days and delayed 1 day relative to breath collection to allow for transit time in the gastrointestinal tract. Faeces from each animal were weighed, pooled within each day and sampled $(10 \%)$ for DM determination $\left(100^{\circ} \mathrm{C}, 48 \mathrm{~h}\right)$.

Samples of herbage for DMD determination were collected each morning before grazing by hand plucking at the height to which the sheep had grazed on the previous day, in order to imitate any selective grazing of sward components. Herbage samples were dried $\left(60^{\circ} \mathrm{C}, 72 \mathrm{~h}\right)$, ground to pass through a $1-\mathrm{mm}$ sieve, pooled for each period of $\mathrm{CH}_{4}$ measurement and analysed by NIRS for chemical composition and apparent DMD. The NIRS was calibrated against a wet chemistry database for chemical composition estimates and against samples from previous in vivo digestibility measurements for DMD (Corson et al. 1999). Gross energy (GE, MJ/kg DM) content in herbage was determined by an adiabatic bomb calorimeter (Gallenkamp Autobomb; Loughborough, Leics., UK). 
At the start of $\mathrm{P}_{1}$ and $\mathrm{P}_{4}$ two $0 \cdot 15-\mathrm{m}^{2}$ quadrats of herbage were cut to ground level using hand-clippers. Samples were pooled, washed, dried $\left(60^{\circ} \mathrm{C}, 72 \mathrm{~h}\right)$ and used for determination of herbage mass and botanical composition ( $\% \mathrm{DM}$; by manual separation).

At the end of the last day of breath collection in each measurement period rumen contents $(15-20 \mathrm{ml})$ were sampled from each sheep by stomach tube within $1 \mathrm{~h}$ of removal from grazing $(08.00 \mathrm{~h})$. Samples were squeezed through one layer of cheese cloth, processed (acidified, deproteinized and centrifuged) following the procedures described by Domingue et al. (1991) and then analysed for VFA as described by Hoskin et al. (1995). Because in some cases the rumen content samples were contaminated with saliva, only the ratios of molar proportions of acetic acid to propionic acid (A/P) were calculated. It was assumed that $\mathrm{A} / \mathrm{P}$ did not vary with the sampling position (Bryant 1964).

\section{Data calculation and statistical analyses}

Daily GE intake (GEI) was calculated from the estimated DMI and GE content of forages and expressed as $\mathrm{MJ} / \mathrm{kg} \mathrm{LW}{ }^{0.75}$. In this study, the term ${ }^{'} \mathrm{CH}_{4}$ production' is the absolute daily production ( $\mathrm{g} /$ day), whereas the proportion of the daily GEI ( $\%$ GEI) lost as $\mathrm{CH}_{4}$ is the $\mathrm{CH}_{4}$ yield. The term $\mathrm{CH}_{4}$ emission refers both to $\mathrm{CH}_{4}$ production and $\mathrm{CH}_{4}$ yield, as well as to $\mathrm{CH}_{4}$ production rate per unit of intake.

The persistence of sheep rankings (low or high) for $\mathrm{CH}_{4}$ emission was assessed from: (1) a split-plot analysis of variance and (2) a between-periods rank order correlation analysis. In the split-plot analysis of variance (Gill 1986), the daily $\mathrm{CH}_{4}$ production and $\mathrm{CH}_{4}$ yield, were analysed using the GLM procedure of SAS (SAS 1987). Effects of $\mathrm{CH}_{4}$ emission subgroups ( $\mathrm{S}$, low or high emitters) were tested using the animal (A) within emission subgroups $(\mathrm{A}(\mathrm{S})$ ) component as the error term; whereas the effects of periods $(\mathrm{P})$ and the interaction $\mathrm{S} \times \mathrm{P}$ were tested using $\mathrm{P} \times \mathrm{A}(\mathrm{S})$ as the error term. The PDIFF option in SAS (SAS 1987) was used to test the differences between least squared means. If the $\mathrm{S} \times \mathrm{P}$ interaction from the analysis of variance of $\mathrm{CH}_{4}$ production (or yield) data was statistically significant, it implied that sheep subgroups (S) were not persistent in $\mathrm{CH}_{4}$ production (or yield) even when the $\mathrm{S}$ main effects were significant. The influence of $\mathrm{LW}$ or $\mathrm{LW}^{0.75}$ on $\mathrm{CH}_{4}$ production (and yield) was assessed by including it as a covariate in the model of analysis of variance.

For the correlation analysis, the mean $\mathrm{CH}_{4}$ production and $\mathrm{CH}_{4}$ yield values for individual sheep (irrespective of $\mathrm{CH}_{4}$ emission subgroups) were ranked within each period using the rank procedure of SAS (SAS 1987).

Split-plot analyses of variance, with similar sources of variation to those for analysis of $\mathrm{CH}_{4}$ emission,
Table 1. Chemical composition ( $\mathrm{g} / \mathrm{kg}$ DM) and apparent DM digestibility (DMD) of sheep diets during the experimental periods $(P)$

\begin{tabular}{lrrrrrrr}
\hline \hline \multicolumn{7}{c}{ Feed composition* (g/kg DM) } \\
\cline { 2 - 6 } & CP & SC & NDF & ADF & Lipid & Ash & DMD \\
\hline $\mathrm{P}_{1}$ & 242 & 118 & 365 & 206 & 47 & 108 & $0 \cdot 831$ \\
$\mathrm{P}_{2}$ & 221 & 104 & 413 & 236 & 42 & 108 & $0 \cdot 783$ \\
$\mathrm{P}_{3}$ & 225 & 113 & 375 & 216 & 47 & 107 & $0 \cdot 803$ \\
$\mathrm{P}_{4}$ & 293 & 87 & 397 & 210 & 47 & 110 & $0 \cdot 833$ \\
\hline \hline
\end{tabular}

* Abbreviations: DM, dry matter; CP, crude protein; SC, soluble carbohydrates; NDF, neutral detergent fibre; ADF, acid detergent fibre.

Table 2. Mean ( \pm s.D.) daily maximum and minimum temperatures $\left({ }^{\circ} \mathrm{C}\right)$ and relative humidities $(\%)$ during the experimental periods $(P)$

\begin{tabular}{ccrc}
\hline \hline & $\begin{array}{c}\text { Maximum } \\
\text { temperature } \\
\left({ }^{\circ} \mathrm{C}\right)\end{array}$ & $\begin{array}{c}\text { Minimum } \\
\text { temperature } \\
\left({ }^{\circ} \mathrm{C}\right)\end{array}$ & $\begin{array}{c}\text { Relative } \\
\text { humidity } \\
(\%)\end{array}$ \\
\hline $\mathrm{P}_{1}$ & $19 \cdot 1 \pm 2 \cdot 26$ & $11 \cdot 2 \pm 1 \cdot 75$ & $95 \cdot 2 \pm 1 \cdot 40$ \\
$\mathrm{P}_{2}$ & $17 \cdot 6 \pm 2 \cdot 96$ & $9 \cdot 1 \pm 3 \cdot 75$ & $79 \cdot 8 \pm 10 \cdot 8$ \\
$\mathrm{P}_{3}$ & $20 \cdot 3 \pm 1 \cdot 90$ & $11 \cdot 0 \pm 1 \cdot 65$ & $82 \cdot 2 \pm 9 \cdot 05$ \\
$\mathrm{P}_{4}$ & $22 \cdot 7 \pm 1 \cdot 72$ & $12 \cdot 0 \pm 3 \cdot 08$ & $80 \cdot 5 \pm 5 \cdot 95$ \\
\hline \hline
\end{tabular}

were also carried out for data concerning LW, GEI and $\mathrm{A} / \mathrm{P}$ ratio.

\section{RESULTS}

\section{Diet and weather conditions}

Herbage masses at the start of $\mathrm{P}_{1}$ and $\mathrm{P}_{4}$ were 3050 and $2300 \mathrm{~kg} \mathrm{DM} / \mathrm{ha}$, respectively. At the start of $\mathrm{P}_{1}$, perennial ryegrass and white clover constituted respectively 83 and $13 \%$ of the herbage DM on offer, whereas the corresponding values for $\mathrm{P}_{4}$ were 71 and $21 \%$, respectively.

The diet judged to be selected by the sheep (handplucked samples) was of good quality as seen from its high digestibility and crude protein content (Table 1). Statistical analysis of trends in feed composition was not possible because only one bulked sample was chemically analysed for each period. The diet in $\mathrm{P}_{2}$ appeared to be higher in NDF and ADF and lower in digestibility than other periods, while $\mathrm{P}_{4}$ had a relatively high crude protein and soluble carbohydrate content. Lipid and ash were similar in all periods.

Differences in weather conditions between consecutive periods were small (Table 2). However, the weather tended to be slightly warmer and drier as the experiment progressed. 
Table 3. Mean liveweight $(\mathrm{LW})$, daily gross energy intake $(\mathrm{GEI})$, methane $\left(\mathrm{CH}_{4}\right)$ production $(\mathrm{g} /$ day) and yield (\% GEI) and acetate/propionate $(A / P)$ ratio for sheep subgroups $\left(S\right.$ : low or high $\mathrm{CH}_{4}$ emitters) during the experimental periods $(P)$. Statistical non-significance $($ N.S. $=\mathrm{P}>0 \cdot 05)$ or significance $(* * \mathrm{P}<0 \cdot 01$ and $* * * \mathrm{P}<0 \cdot 001)$ of $S, P$ and $S \times P$ effects are indicated as superscripts of their respective standard errors

\begin{tabular}{|c|c|c|c|c|c|c|c|c|c|c|c|c|c|}
\hline & \multicolumn{5}{|c|}{ Low $\mathrm{CH}_{4}$ emitters } & \multicolumn{5}{|c|}{ High $\mathrm{CH}_{4}$ emitters } & \multicolumn{3}{|c|}{ Standard errors } \\
\hline & $\mathrm{P}_{1}$ & $\mathrm{P}_{2}$ & $\mathrm{P}_{3}$ & $\mathrm{P}_{4}$ & Mean & $\mathrm{P}_{1}$ & $\mathrm{P}_{2}$ & $\mathrm{P}_{3}$ & $\mathrm{P}_{4}$ & Mean & S & $\mathrm{P}$ & $\mathrm{S} \times \mathrm{P}$ \\
\hline LW (kg/head) & $45 \cdot 5$ & $49 \cdot 7$ & $54 \cdot 7$ & $55 \cdot 7$ & $51 \cdot 4$ & $44 \cdot 0$ & $46 \cdot 6$ & $50 \cdot 7$ & $50 \cdot 2$ & $47 \cdot 9$ & $2 \cdot 13^{\text {N.s. }}$ & $0 \cdot 31^{* * *}$ & $0 \cdot 46^{* *}$ \\
\hline GEI (MJ/kg LW $\left.{ }^{0.75}\right)$ & $2 \cdot 39$ & 1.95 & $2 \cdot 29$ & $2 \cdot 36$ & $2 \cdot 25$ & $2 \cdot 21$ & 1.83 & $2 \cdot 15$ & $2 \cdot 39$ & $2 \cdot 14$ & $0 \cdot 110^{\text {N.S. }}$ & $0.058^{* * *}$ & $0 \cdot 088^{\text {N.S. }}$ \\
\hline \multicolumn{14}{|l|}{$\mathrm{CH}_{4}$ emission } \\
\hline g/day & $23 \cdot 0$ & $32 \cdot 8$ & $32 \cdot 0$ & $27 \cdot 3$ & $28 \cdot 8$ & $37 \cdot 3$ & $37 \cdot 3$ & $31 \cdot 3$ & $36 \cdot 4$ & $35 \cdot 5$ & $2 \cdot 44^{\mathrm{N} . \mathrm{s}}$ & $2 \cdot 19^{\mathrm{N} \cdot \mathrm{s}}$ & $3 \cdot 30^{\text {N.s. }}$ \\
\hline$\%$ GEI & $3 \cdot 04$ & 4.98 & $3 \cdot 85$ & $3 \cdot 13$ & 3.75 & $5 \cdot 41$ & $6 \cdot 42$ & $4 \cdot 22$ & $4 \cdot 56$ & $5 \cdot 15$ & $0 \cdot 261^{* *}$ & $0 \cdot 322^{* *}$ & $0 \cdot 487^{\text {N.s. }}$ \\
\hline $\mathrm{A} / \mathrm{P}$ & $3 \cdot 20$ & $2 \cdot 67$ & $2 \cdot 90$ & 3.63 & $3 \cdot 10$ & $3 \cdot 53$ & $2 \cdot 90$ & $3 \cdot 15$ & $3 \cdot 50$ & $3 \cdot 27$ & $0 \cdot 106^{\text {N.S. }}$ & $0 \cdot 070^{* * *}$ & $0 \cdot 107^{\text {N.S. }}$ \\
\hline
\end{tabular}

Degrees of freedom for $\mathrm{S}, \mathrm{P}$ and $\mathrm{S} \times \mathrm{P}$ are respectively 5,15 and 15 .

Table 4. Between-periods rank order correlation coefficients for methane $\left(\mathrm{CH}_{4}\right)$ production $(\mathrm{g} /$ day) and yield $(\% G E I)$

\begin{tabular}{|c|c|c|c|c|c|c|}
\hline & \multicolumn{3}{|c|}{$\mathrm{CH}_{4}$ (g/day) } & \multicolumn{3}{|c|}{$\mathrm{CH}_{4}(\% \mathrm{GEI})$} \\
\hline & $\mathrm{P}_{1}$ & $\mathrm{P}_{2}$ & $\mathrm{P}_{3}$ & $\mathrm{P}_{1}$ & $\mathrm{P}_{2}$ & $\mathrm{P}_{3}$ \\
\hline $\mathrm{P}_{2}$ & 0.89 & & & $0 \cdot 86$ & & \\
\hline $\mathrm{P}_{3}$ & $-0 \cdot 14$ & 0.04 & & 0.54 & 0.72 & \\
\hline $\mathrm{P}_{4}$ & 0.82 & 0.64 & $-0 \cdot 61$ & 0.71 & $0 \cdot 68$ & $0 \cdot 00$ \\
\hline
\end{tabular}

\section{Methane emission and other animal parameters}

There were no significant effects of $\mathrm{LW}$ or $\mathrm{LW}^{\mathbf{0} 75}$ (covariate) on $\mathrm{CH}_{4}$ production $\left(\mathrm{g} /\right.$ day) or $\mathrm{CH}_{4}$ yield (\% GEI) $(P>0 \cdot 05)$, however there was a significant $\mathrm{S} \times \mathrm{P}$ interaction $(P<0 \cdot 01)$ between methane emission subgroup and period for $\mathrm{LW}(\mathrm{kg})$ (Table 3$)$. In $\mathrm{P}_{1}$, low emitters were $1.51 \mathrm{~kg}$ heavier $(P=0.03)$ than the high emitters and this difference became larger as the experiment progressed $\left(3 \cdot 10,3.97\right.$ and $5.58 \mathrm{~kg}$ at $\mathrm{P}_{2}, \mathrm{P}_{3}$ and $\mathrm{P}_{4}$, respectively; $\left.P<0.001\right)$. Liveweight of both low and high emitters increased $(P<0 \cdot 001)$ from $\mathrm{P}_{1}$ to $\mathrm{P}_{3}$, but was similar $(P>0.05)$ between $\mathrm{P}_{3}$ and $\mathrm{P}_{4}$ (Table 3).

GEI $\left(\mathrm{MJ} / \mathrm{kg} \mathrm{LW}{ }^{0.75}\right)$ did not differ between $\mathrm{CH}_{4}$ emission subgroups (S), but was significantly different between periods $(P<0 \cdot 001)$. GEIs $\left(\mathrm{MJ} / \mathrm{kg} \mathrm{LW}^{0.75}\right)$ were similar during $\mathrm{P}_{1}(2 \cdot 30), \mathrm{P}_{3}(2 \cdot 22)$ and $\mathrm{P}_{4}(2 \cdot 38)$ and higher than values during $\mathrm{P}_{2}(1 \cdot 89 ; P<0 \cdot 001)$.

Over the four periods the low emitters did not produce significantly less total $\mathrm{CH}_{4}(\mathrm{~g} /$ day) than the high emitters $(28.9$ v. $35.5 ; P=0.09)$, however the $\mathrm{CH}_{4}$ yields (\% GEI) of the low emitters were significantly lower than those of the high subgroup (3.75 v. $5 \cdot 15 ; P<0 \cdot 01$ ) (Table 3). There were also significant period effects on $\mathrm{CH}_{4}$ yield $(P<0 \cdot 01)$, but not upon $\mathrm{CH}_{4}$ production (g/day). Methane yields $(\% \mathrm{GEI})$ at $\mathrm{P}_{1}$ (4.23), $\mathrm{P}_{3}(4 \cdot 03)$ and $\mathrm{P}_{4}(3 \cdot 84)$ were similar, but lower $(P<0 \cdot 01)$ than $\mathrm{P}_{2}(5 \cdot 70)$.

Low and high emitters did not differ in $\mathrm{A} / \mathrm{P}$ ratio (Table 3), however there were significant effects of period $(\mathrm{P})$. A/P ratio in rumen fluid differed throughout all the periods of this study, being $3 \cdot 36,2 \cdot 78,3 \cdot 03$ and 3.57 in $\mathrm{P}_{1}, \mathrm{P}_{2}, \mathrm{P}_{3}$ and $\mathrm{P}_{4}$, respectively $(P<0.001)$.

\section{Persistence of between-sheep differences in $\mathrm{CH}_{4}$ emission}

The fact that there was no $\mathrm{S} \times \mathrm{P}$ interaction $(P>0 \cdot 05)$ for $\mathrm{CH}_{4}$ yield $(\% \mathrm{GEI})$ and that this parameter was significantly influenced by $\mathrm{S}$ (Table 3), indicates that there was a consistent difference between low and high $\mathrm{CH}_{4}$ emitters throughout the 5-month study. This observation was corroborated by the generally high $(P<0.05)$ rank order correlation coefficients for $\mathrm{CH}_{4}$ yield between the periods (Table 4), except that for $\mathrm{P}_{3}$ and $\mathrm{P}_{4}$, which was null. The persistence of the difference between the high and low emission subgroups in $\mathrm{CH}_{4}$ yield can be seen in Fig. 1: the high subgroup was higher than the low subgroup throughout, significantly so in $\mathrm{P}_{1}, \mathrm{P}_{2}$ and $\mathrm{P}_{4}$.

$\mathrm{CH}_{4}$ production (g/day) did not show the same pattern since differences between low and high $\mathrm{CH}_{4}$ emitters were not significantly different $(P=0 \cdot 09)$ despite the lack of $\mathrm{S} \times \mathrm{P}$ interaction $(P>0.05)$ (Table 3$)$. In addition, for $\mathrm{CH}_{4}$ production, no clear pattern was observed in the rank order coefficients of correlation between consecutive periods (Table 4).

\section{DISCUSSION}

The objective of the work was to test whether the observed large differences in $\mathrm{CH}_{4}$ yield (\% GEI) 


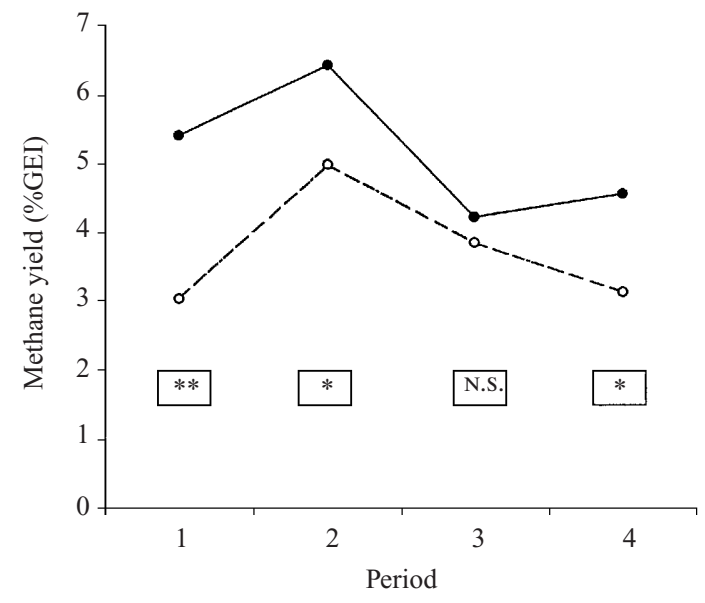

Fig. 1. The pattern of methane emission ( $\%$ gross energy intake; \% GEI) in sheep selected as high (-) or low $(\bigcirc--\bigcirc)$ emitters across the four experimental periods. The symbols in the boxes indicate the significance of differences between means within periods: ${ }^{*} P<0.01$; ${ }^{*} P<0.05$; N.S., not significant.

between animals reported by Blaxter \& Clapperton (1965), Demeyer \& van Nevel (1975), Lassey et al. (1997) and Ulyatt et al. (1999) persist in time under grazing conditions. The significant effect of $\mathrm{S}$ (Table 3 , Fig. 1), the lack of effect of $\mathrm{S} \times \mathrm{P}$ upon $\mathrm{CH}_{4}$ yield (Table 3), and strong between-period correlation coefficients for $\mathrm{CH}_{4}$ yield (Table 4) indicate that sheep in the present study persisted in their rankings for $\mathrm{CH}_{4}$ emission (low or high). This finding contrasts with our preliminary observations (Pinares-Patiño 2000), when there was a lack of persistence when sheep selected as low or high $\mathrm{CH}_{4}$ emitters $(\mathrm{g} / \mathrm{kg}$ DMI) under grazing, were brought indoors, fed dried feeds at restricted levels (1.2 maintenance), and had their feeding conditions changed between periods of measurement.

The high repeatability of $\mathrm{CH}_{4}$ yield between periods observed in the present study, suggests that feeding conditions which maximize voluntary feed intake (e.g. generous allowance of good quality pasture), favour the expression and persistence of betweensheep differences in $\mathrm{CH}_{4}$ yield. It must be noted, however, that these differences weakened as the experiment progressed (Table 3 ).

Sheep selected as low or high $\mathrm{CH}_{4}$ emitters did not differ $(P>0.05)$ in their daily GEI $\left(\mathrm{MJ} / \mathrm{kg} \mathrm{LW}{ }^{0.75}\right)$ within any period (Table 3 ). Nevertheless, while the initial difference in LW between them became larger with the progress of the experimental periods (Table 3), the differences in $\mathrm{CH}_{4}$ yield were maintained. This suggests that in comparison with the high emitters, the low emitters retained a greater proportion of their daily GEI as body energy. $\mathrm{CH}_{4}$ yield is negatively correlated with rumen particulate outflow rate (particulate FOR) (Blaxter \& Clapperton 1965; Demeyer \& van Nevel 1975; Okine et al. 1989; Pinares-Patiño et al. 2003), and on foragebased diets, lower $\mathrm{A} / \mathrm{P}$ ratios and $\mathrm{CH}_{4}$ yields are expected from the ingestion of diets with higher contents of legumes and soluble carbohydrates (Demeyer \& van Nevel 1975; Beever 1993; Benchaar et al. 2001). In the present study, the $A / P$ tended to be lower in the low emitters compared with the high emitters. However, whether differences in particulate FOR or diet selection (or both) were responsible for the consistent differences in $\mathrm{CH}_{4}$ yield between low and high $\mathrm{CH}_{4}$ emitters, is unknown.

Despite the fact that the perennial ryegrass/white clover-dominant pasture used for this experiment covered the period from spring (early October; $\mathrm{P}_{1}$ ) to mid summer (late February; $\mathrm{P}_{4}$ ), there were no dramatic changes in pasture chemical composition (Table 2). DM digestibility was high throughout the measurement periods. The small decrease in DM digestibility, together with increased fibre in $\mathrm{P}_{2}$ (late November), probably reflected an increase in grass stem due to flowering (Ulyatt 1980). It is probable that the relatively high $\mathrm{CH}_{4}$ yields (\% GEI) and low GEIs $\left(\mathrm{MJ} / \mathrm{kg} \mathrm{LW}^{0.75}\right)$ in both the high and low emitters in $\mathrm{P}_{2}$ (Table 3, Fig. 1) were due to this decrease in pasture quality. This is in agreement with the observations by Blaxter \& Clapperton (1965), who concluded that above maintenance levels of feeding, $\mathrm{CH}_{4}$ yield is inversely related to feeding level and feed apparent digestibility.

The mean daily $\mathrm{CH}_{4}$ yield ( $\%$ GEI) observed in the present study (4.5) was similar to that (4.6) reported by Lassey et al. (1997) for grazing sheep. Both these experiments used young wether sheep and the $\mathrm{SF}_{6}$ tracer technique for $\mathrm{CH}_{4}$ measurement. It has been observed (Ulyatt et al. 2002), also in grazing conditions, that mature sheep have a methane yield around $6.0 \%$ GEI. These latter values are similar to those commonly found in respiration calorimeters measurements for mature sheep fed on grass hay (e.g. 6.5; Blaxter \& Wainman 1964). Thus, it can be suggested that young sheep have a lower $\mathrm{CH}_{4}$ yield compared with mature sheep, perhaps because they select a more nutritious component of the pasture, or perhaps because their rumens are not fully developed.

The results of the work showed that the differences between sheep in $\mathrm{CH}_{4}$ yield found by Blaxter \& Clapperton (1965), Demeyer \& van Nevel (1975), Lassey et al. (1997) and Ulyatt et al. (1999) can persist for up to 6 months. This result needs confirmation and testing over a longer time span, because if it is true and is under genetic control, it raises the possibility of selecting for sheep of reduced methane emission. If these differences can be shown to persist there is a need to determine how the individual animal 
controls an activity that is the prerogative of the methanogenic microorganisms.

Dr G. C. Waghorn and I. D. Shelton (AgResearch Grasslands), J. Purchas (Massey University), and C. F. Walker and A. M. S. McMillan (NIWA) are thanked for their assistance. C. S. Pinares-Patiño was in receipt of a postgraduate scholarship from the New Zealand Ministry of Foreign Affairs and Trade. This research was funded by the NZ Foundation for Research, Science and Technology and by the NZ Ministry of Agriculture and Fisheries.

\section{REFERENCES}

BeEver, D. E. (1993). Rumen function. In Quantitative Aspects of Ruminant Digestion and Metabolism (Eds J. M. Forbes \& J. France), pp. 187-215. Wallingford: CAB International.

Benchaar, C., Pomar, C. \& Chiquette, J. (2001). Evaluation of dietary strategies to reduce methane production in ruminants: a modelling approach. Canadian Journal of Animal Science 81, 563-574.

Blaxter, K. L. \& Clapperton, J. L. (1965). Prediction of the amount of methane produced by ruminants. British Journal of Nutrition 19, 511-522.

Blaxter, K. L. \& Wainman, F. V. (1964). The utilization of the energy of different rations by sheep and cattle for maintenance and for fattening. Journal of Agricultural Science, Cambridge 63, 113-128.

Bryant, A. M. (1964). Variations in the $\mathrm{pH}$ and volatile fatty acid concentration within the bovine reticulorumen. New Zealand Journal of Agricultural Research 7, 694-706.

Corson, D. C., Waghorn, G. C., Ulyatt, M. J. \& Lee, J. (1999). Forage analysis and livestock feeding. Proceedings of the New Zealand Grassland Association 61, 127-132.

Crutzen, P. J. (1995). The role of methane in atmospheric chemistry and climate. In Ruminant Physiology: Digestion, Metabolism, Growth and Reproduction. Proceedings of the Eighth International Symposium on Ruminant Physiology (Eds W. V. Engelhardt, S. Leonhard-Marek, G. Breves \& D. Giesecke), pp. 291-315. Stuttgart: Ferdinand Enke Verlag.

Demeyer, D. I. \& van Nevel, C. J. (1975). Methanogenesis, an integrated part of carbohydrate fermentation, and its control. In Digestion and Metabolism in the Ruminant. Proceedings of the 4th International Symposium on Ruminant Physiology (Eds I. W. McDonald \& A. C. I. Warner), pp. 366-382. University of New England, Armidale, Australia: The University of New England Publishing Unit.

Domingue, B. M. F., Dellow, D. W., Wilson, P. R. \& BARry, T. N. (1991). Nitrogen metabolism, rumen fermentation, and water absorption in red deer, goats and sheep. New Zealand Journal of Agricultural Research 34, 391-400.

Gibbs, M. J., Lewis, L. \& Hoffman, J. S. (1989). Reducing Methane Emissions from Livestock: Opportunities and Issues. Rep. EPA 400/1-89/002. Washington, DC: U.S. Environmental Protection Agency.

GiLL, J. L. (1986). Repeated measurement: sensitive tests for experiments with few animals. Journal of Animal Science 63, 943-954.

Hodgson, J. (1990). Grazing Management, Science into Practice. Harlow: Longman Scientific and Technical.

Hoskin, S. O., Stafford, K. J. \& Barry, T. N. (1995). Digestion, rumen fermentation and chewing behaviour of red deer fed fresh chicory and perennial ryegrass. Journal of Agricultural Science, Cambridge 124, 289-295.

Houghton, J. (1997). Global Warming: The Complete Briefing, 2nd edition. Cambridge: Cambridge University Press.

Johnson, D. E., Hill, T. M., Ward, G. M., Johnson, K. A., Branine, M. E., Carmean, B. R. \& Lodman, D. W. (1993). Ruminants and other animals. In Atmospheric Methane: Sources, Sinks, and Role in Global Change (Ed. M. A. K. Khalil), pp. 219-229. Berlin: Springer-Verlag.

Johnson, D. E., WARD, G. M. \& RAMsey, J. J. (1996). Livestock methane: current emissions and mitigation potential. In Nutrient Management of Food Animals to Enhance and Protect the Environment (Ed. E. T. Kornegay), pp. 219-233. New York: CRC Press Inc.

Johnson, K., Huyler, M., Westberg, H., Lamb, B. \& Zimmerman, P. (1994). Measurement of methane emissions from ruminant livestock using a $\mathrm{SF}_{6}$ tracer technique. Environmental Science and Technology $\mathbf{2 8}$, 359-362.

Lassey, K. R., Ulyatt, M. J., Martin, R. J., Walker, C. F. \& Shelton, I. D. (1997). Methane emissions measured directly from grazing livestock in New Zealand. Atmospheric Environment 31, 2905-2914.

LENG, R. A. (1993). Quantitative ruminant nutrition - a green science. Australian Journal of Agricultural Research 44, 363-380.

McAllister, T. A., Okine, E. K., Mathison, G. W. \& Cheng, K.-J. (1996). Dietary, environmental and microbiological aspects of methane production in ruminants. Canadian Journal of Animal Science 76, 231-243.

Ministry for the Environment (1997). The State of New Zealand's Environment. Wellington, New Zealand: Ministry for the Environment and GP Publications.

Mosier, A. R., Duxbury, J. M., Freney, J. R., Heinemeyer, O., Minami, K. \& Johnson, D. E. (1998). Mitigating agricultural emissions of methane. Climatic Change 40, 39-80.

Okine, E. K., Mathison, G. W. \& Hardin, R. T. (1989). Effects of changes in frequency of reticular contractions on fluid and particulate passage rates in cattle. Journal of Animal Science 67, 3388-3396.

Pinares-Patiño, C. S. (2000). Methane Emission from Forage-fed Sheep, a Study of Variation Between Animals. Ph.D. thesis, Massey University, Palmerston North, New Zealand.

Pinares-Patiño, C. S., Ulyatt, M. J., Lassey, K. R., BarRY, T. N. \& Holmes, C. W. (2002). Rumen function and digestion parameters associated with differences between sheep in methane emissions when fed chaffed lucerne hay. Journal of Agricultural Science, Cambridge 140, 205-214.

SAS (1987). SAS/STAT Guide for Personal Computers (Version 6). Cary, NC: SAS Institute, Inc. 
Ulyatt, M. J. (1980). The feeding value of temperate pastures. In Grazing Animals. World Animal Science, Vol. 16 (Ed. F. H. W. Morley), pp. 125-141. Amsterdam: Elsevier.

Ulyatt, M. J., Baker, S. K., McCrabb, G. J. \& Lassey, K. R. (1999). Accuracy of $\mathrm{SF}_{6}$ tracer technology and alternatives for field measurements. Australian Journal of Agricultural Research 50, 1329-1334.

Ulyatt, M. J., Lassey, K. R., Shelton, I. D. \& Walker, C. F. (2002). Seasonal variation in methane emission from dairy cows and breeding ewes grazing ryegrass/white clover pasture in New Zealand. New Zealand Journal of Agricultural Research $\mathbf{4 5}$.

UNFCCC (1999). Report on the In-depth Review of the Second National Communication of New Zealand (FCCC/ IDR.2/NZL). Geneva: United Nations Framework Convention on Climate Change.

van Nevel, C. J. \& Demeyer, D. I. (1996). Control of rumen methanogenesis. Environmental Monitoring and Assessment 42, 73-97. 
Persistence of differences between sheep in methane emission under generous grazing conditions

Pinares-Patiño, C. S.

2003

http://hdl.handle.net/10179/9679

22/04/2023 - Downloaded from MASSEY RESEARCH ONLINE 